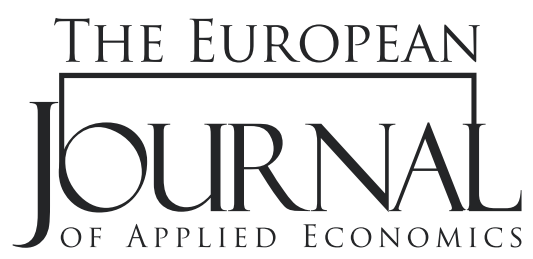

EJAE 2020, 17(1): 128 - 145

ISSN 2406-2588

UDK: $338.48-44(497.11)$

005.96:338.48

DOI: 10.5937/EJAE17-21424

Original paper/Originalni naučni rad

\title{
THE INFLUENCE OF HUMAN RESOURCES ON THE DEVELOPMENT OF LEADING TOURISM DESTINATIONS IN SERBIA
}

\author{
Nikolina Kordić*, Snežana Milićević \\ Faculty of Hotel Management and Toursim in Vrnjačka Banja, \\ University of Kragujevac, \\ Serbia
}

\begin{abstract}
:
The aim of this paper is to show that the number of tourism overnight stays and the number of beds are related with the scope and dynamics of employment in the hotel industry of Serbia. Serbia's most developed destinations (in the field of city tourism Belgrade and Novi Sad, spa tourism - Vrnjačka Banja and Sokobanja, and mountain tourism Zlatibor and Kopaonik) were chosen as the subject of research. The first part of the paper discusses the connection between the study of tourist destinations, on the one hand, and human resources, on the other hand. In the second part of the paper, corresponding conclusions are drawn regarding the influence of human resources on the development of the leading tourist destinations in Serbia by using systematization and presentation of statistical data, by analyzing the quantification of the effect of employment on tourism overnight stays, based on regression analysis, using the analytic-synthetic and comparative methods.
\end{abstract}

\section{Article info:}

Received: April 22, 2019

Correction: June 10, 2019

Accepted: August 24, 2019

\section{Keywords:}

tourism destination employment, overnight stays,

accommodation capacity, Serbia.

\section{INTRODUCTION}

Tourism is one of the world's leading industries. In 2017, 1,326 million international tourist arrivals took place. That same year, international tourism revenue amounted to 1,340 billion US dollars (UNWTO, 2018). In 2017, tourism participated in the world GDP (taking into account the direct, indirect and multiplied - induced effects) with 10\%, and in total world exports with 6.5\% (WTTC World, 2018). In 2017, Serbia was visited by approximately 3.1 million tourists, of which 1.6 million were national, and 1.5 million international. From 2013 to 2017, an increase in the number of tourists, especially foreign tourists, and overnight stays was noted in this country (Republic Statistical Office of Serbia. 
Statistical Yearbook of Serbia, 2018). In 2017, tourism participated in the GDP of Serbia with 6.7\% (taking into account the direct, indirect and multiplied - induced effects), and in total exports with 7.1\% (WTTC World, 2018). Tourism is the world's largest generator of jobs. In 2017, 118,454,000 jobs directly involved in tourism were registered (employees in hotels, restaurants, and other types of establishments in the hotel industry, in travel agencies, in entertainment and recreation facilities, in airlines and other types of traffic organizations engaged in passenger transport, with the exception of suburban traffic), which accounted for $3.8 \%$ of the total scope of global employment. Taking into account other jobs indirectly related to tourism, about 313,221,000 jobs were registered for the same year, which amounted to $9.9 \%$ of total world employment. Every 10 th job in the world belonged to the tourism sector (WTTC World, 2018). In Serbia in 2017, 37,000 jobs directly involved in tourism were registered, which accounted for $1.9 \%$ of the total scope of employment. This was twice as low compared to the global average. That same year, the number of jobs indirectly linked to tourism amounted to 96,500 , accounting for $4.9 \%$ of total employment in Serbia (WTTC Serbia, 2018) which was also twice as low as the global average. Every 20th job is directly or indirectly associated with the tourism industry.

Tourism services are processes involving a significant interaction between tourists and employees. The temporary stay of tourists in a tourist destination imposes the provision of hotel services. Therefore, the hotel industry as the receptive element of tourist destinations is considered to be a key indicator of the degree of its development and the assessment of its quality. The hotel industry requires the involvement of a large number of employees. The largest number of employees in the tourism industry can be found precisely in the hotel industry. We therefore focus on the hotel industry employment as a representative part of the total number of employees in a tourist destination.

It is important for Serbian tourism that there be human resources who possess the knowledge and skills for the valuation of natural and anthropogenic attractions, which abound in Serbia. In light of this data, however, Serbia has lagged behind the global average. The data referring to human resources indicate that Serbia does not have the required scope of employment in this area. Therefore, the main objective of this paper is to consider in detail the interdependence of the scope of employment and the basic indicators of touristic development, such as the volume of tourist overnight stays and accommodation capacity. This is the initial step in considering the effect of human resources on the development of tourist destinations. In line with the need to point out the importance of human resources for the development of tourism in Serbia, research was conducted in destinations that are taken as an example and basis for analysis. These destinations (Belgrade, Novi Sad, Vrnjačka Banja, Sokobanja, Zlatibor, and Kopaonik) are representative, especially regarding tourism overnight stays and accommodation facilities. It is to be expected that leading tourism destinations have devoted extraordinary attention to employees in tourism sector, primarily in hotel industry.

\section{LITERATURE REVIEW}

Today tourism has great social significance. Goeldner \& Brent Ritchie (2009) emphasize that tourism will continue growing in the future under conditions of fundamental changes that will occur under the influence of high technology, which will require a greater need for human contact. Stasiak (2013) points out that hotels have long ceased to be the only elements of the tourist infrastructure, but have become places where a complex tourist experience is enjoyed, and that requires the appropriate personnel able to meet the expectations of guests. 
Kosar \& Kordić (2018) point to the complexity of the hotel product and the wide range of components, i.e., services that meet the many and varied needs of consumers. The focus of the future study of tourism theory and practice will be the hotel product as the basis of the tourism product, i.e., the tourist destination product. Kosar \& Rašeta (2005) state that the quality of the hotel product is largely determined by the quality of human resources, and argue that the quality of the hotel product is integrated into the quality of the tourist destination offer. The complexity and diversity of tourist destination products are reflected in different approaches to the conceptual definition of the tourist destination, which Milićević \& Djordjević (2016) discuss. According to them, tourist destinations are places where all the content is subordinated to tourism and its development, as well as cities, large metropolises, and entire countries, where tourism is manifested as an aspect of development.

The tourist destination is, therefore, a starting point for the study of tourism. Saraniemi \& Kylan (2011) insist on an innovative developmental concept of tourism that is based on the destination approach and that involves all stakeholders. Tourist consumers are important stakeholders. Therefore, it is particularly necessary to understand their consumer behavior, according to the Seddighe \& Theocharous (2002), when selecting a tourist destination. Popesku (2011) believes that the destination approach to the study of tourism treats tourist destinations as complex systems. Key aspects of these studies refer to the competitiveness and sustainability of tourist destinations, with the focus on the analysis of the tourist experience as a starting basis for the consideration of competitiveness.

Addressing competitiveness of tourist destinations includes quantitative models, such as the Competitiveness Monitor (CM), created by the World Travel and Tourism Council (WTTC). Mazanec, Wober \& Zins (2007) emphasize that this model is widely applicable due to the public availability of data and the possibility of result interpretation by independent research groups. The search for the most acceptable ways to assess the competitiveness of tourist destinations is reflected in the creation of models that contain different sets of factors. Ritchie \& Crouch (2010) discuss the operation of these factors, primarily under the influence of so-called qualifying and amplifying determinants (location, safety and security, price and value, interdependence, awareness and image, carrying capacity) on the increase or decrease in the competitiveness and sustainability of tourist destinations.

Among the many and varied factors of tourist destination competitiveness, a special place belongs to human resources. Gruescu, Nanu \& Tanasie (2009) point out that the tourism industry is based on people, and that human resources development should be the main preoccupation of tourism professionals. According to Vengesayi, Mavondo \& Reisinger (2013), human capital strongly influences the development of a tourism destination. They believe that high quality human resources represent a relevant competitive advantage for tourism destination. Human resources management, according to Ahmmad (2017), implies the process of selection, recruitment of employees, monitoring their development through education, training, the improvement of skills, motivation, the provision of workplace security and safety, their well-being, the betterment of their health, and interpersonal relationships. Brewster, Sparrow, Vernon \& Houldsworth, (2011) suggest that differences in human resource management originate from the cultural and institutional environment of different countries, hence the need for flexibility and understanding of this area of management.

Given that people are carriers of organizational knowledge, human resource management manifests itself as an important factor in economic development. Petrović \& Stanišić (2015) believe that knowledge as a vital developmental resource of economic progress has not been sufficiently exploited. This has been shown by the research on the effect of the knowledge economy index (KEI) on the gross domestic product (GDP) in countries in transition. 
Emotional intelligence is an important feature of human resources. Pekaar, Linden, Bakker, \& Born (2017) have demonstrated that different levels of the emotional intelligence of employees significantly affect the quality of their contact with clients in the service industry. Wolfe \& Kim (2013) have presented the results of surveys conducted among hotel managers in a hotel company in the Midwestern United States, indicating that certain components of emotional intelligence (interpersonality, general mood, and stress management skills) are indicators of job satisfaction. Employee motivation is an essential component of job satisfaction. Sarajevo (2016) states that today managers are constantly engaged in employee motivation, especially in times of crisis.

The tourism sector offers wide and diverse employment opportunities. Unković (2017) points out that the demand for professionals in the field of economics and management in tourism is dominant thanks to a large number of tourist companies that operate rationally and respond to market demands. However, Baum (2007) believes that traditional employment models still exist in developing countries, which slows down their tourism development. Similar problems are also identified in the hotel industry of Serbia, especially regarding the unsatisfactory qualification structure of employees, as well as low wages, as stated by Kordić \& Milićević (2018).

Therefore, strategic human resource management is of great importance for the development of tourism and the hotel industry, as emphasized by Čerović (2013), where employee performance, motivation, and reward should be analyzed thoroughly. Given that the hotel industry is a service industry, and that it engages a substantial scope of employment, Hoque (2013) points out that the effect of human resource management on organizational and technological changes, innovative business strategies, and economic results in the industry should be subject to continuous analyses. The effect of human resources on tourist destination competitiveness is often emphasized in many scientific and professional circles. The research conducted to quantify the effect of human resources on tourist destination competitiveness, according to Milićević \& Petrović (2018), shows a statistically significant relationship between the number of employees and gross earnings in tourism in the EU member countries and their competitiveness as tourist destinations.

\section{EMPLOYMENT AS A FACTOR OF TOURISM DEVELOPMENT IN SERBIA}

Serbia is considered to be an attractive tourist destination whose potential has not been exploited sufficiently. In this sense, Serbia awaits a number of activities that, among other things, refer to sustainable business improvement, legal environment, business climate, innovativeness, brand strengthening, and reputation (Teodorović \& Popesku, 2017). In accordance with the development goals of the Tourism Development Strategy of the Republic of Serbia for the period 2016-2025, changes in the structure of accommodation facility offers are envisaged in terms of increasing the orientation towards hotels. Accordingly, an increase in the number of employees whose jobs are directly involved in the tourism sector is expected.

The importance of the realization of the objective related to employment should be noted, all the more so because, in the previous strategy, the actual number of employees was about one-third lower than expected (Ministry of Trade, Tourism, and Telecommunications, 2016).

The effect of human resources on the development of Serbia as a tourist destination has not been given adequate attention, as can be seen from Table 1. 
Table 1 presents the data pertaining to the world's leading tourist destinations, as well as the Balkan countries and the region, in order to consider the situation closely and assess the prospects in Serbia. It is evident that Serbia is lagging behind. Countries where tourism is a priority bearer of economic development, as reflected by the share in the total scope of employment, which is also expected in the future, are primarily Malta, Greece, and Croatia, with a share of over 10\% directly employed in the tourism sector. At the same time, including employees whose jobs are indirectly related to tourism, the contribution of tourism exceeds $20 \%$ of the total employment in the mentioned countries. When it comes to the total (direct and indirect) contribution of tourism to the number of employees, Albania, Cyprus, Montenegro, Austria, Italy, and Spain stand out. Serbia is in second-to-last place when it comes to the direct share of employees in tourism in relation to the total number of employees, and when it comes to the overall contribution of tourism expressed in the number of direct and indirect jobs, it is in last place. It is envisaged that an increase of only $0.1 \%$ in direct jobs, and $0.3 \%$ in the total (direct and indirect) jobs of the tourism sector will happen by 2028, which will position Serbia in last place compared to the projections in the mentioned countries.

Table 1 - The share of employees in tourism in relation to the total scope of employment (in \%)

\begin{tabular}{|c|c|c|c|c|}
\hline \multirow{2}{*}{ Territory } & \multicolumn{2}{|c|}{ Share of directly employed } & \multicolumn{2}{|c|}{ Share of directly and indirectly employed } \\
\hline & 2017 state & 2028 projection & 2017 state & 2028 projection \\
\hline World & 3.8 & 4.2 & 9.9 & 11.6 \\
\hline Malta & 15.7 & 20.1 & 28.3 & 35.4 \\
\hline Greece & 12.2 & 13.3 & 24.8 & 28.5 \\
\hline Croatia & 10.1 & 11.8 & 23.5 & 27.2 \\
\hline Albania & 7.7 & 8.8 & 24.1 & 27.3 \\
\hline Montenegro & 7.6 & 8.1 & 19.3 & 21.5 \\
\hline Germany & 7.1 & 8.4 & 13.8 & 14.8 \\
\hline Cyprus & 6.9 & 8.4 & 22.7 & 29.1 \\
\hline Austria & 6.5 & 8.3 & 16.1 & 19.2 \\
\hline Italy & 6.5 & 7.5 & 14.7 & 16.5 \\
\hline India & 5.0 & 5.3 & 8.0 & 8.4 \\
\hline Spain & 4.9 & 5.8 & 15.1 & 16.9 \\
\hline France & 4.2 & 5.0 & 10.0 & 11.2 \\
\hline Slovenia & 3.7 & 4.8 & 12.3 & 15.4 \\
\hline China & 3.6 & 4.3 & 10.3 & 14.7 \\
\hline Hungary & 3.5 & 4.1 & 7.3 & 8.0 \\
\hline USA & 3.4 & 3.9 & 8.9 & 10.1 \\
\hline Bosnia and Herzegovina & 3.2 & 4.4 & 11.2 & 15.2 \\
\hline Bulgaria & 2.9 & 4.1 & 10.7 & 13.4 \\
\hline Romania & 2.5 & 2.6 & 6.3 & 6.5 \\
\hline Serbia & 1.9 & 2.0 & 4.9 & 5.2 \\
\hline Macedonia & 1.6 & 1.8 & 6.1 & 7.0 \\
\hline
\end{tabular}

Source: WTTC: TRAVEL \& TOURISM ECONOMIC IMPACT 2018 World, TRAVEL \& TOURISM ECONOMIC IMPACT 2018 Country-data, TRAVEL \& TOURISM ECONOMIC IMPACT 2018 Serbia 


\section{METHODOLOGY}

The methodology applied in this paper is based on the analysis of statistical data from secondary sources. The state in the leading tourist destinations in Serbia was analyzed on the basis of a ten-year observation period (2008-2017). The number of overnight stays and the number of beds were used as indicators of tourist destination development. Accommodation capacity measured by the number of beds is the basic assumption of tourist arrivals and overnight stays. The fact is that there are destinations in Serbia that have a remarkable accommodation capacity, but they are not competitive. The reason for this is the technological obsolescence on the part of the accommodation offer, and therefore nonconformity with modern market demands. Therefore, the number of overnight stays may be considerably lower than the offered accommodation opportunities. The number of employees as a quantitative indicator represents the starting assumption of the growth dynamics of human resources. It is the basis for further qualitative research, which should be done in order to precisely define different forms of human resource impact on a tourism destination development. In this paper, by using the available data presented in tables, fluctuations in these indicators were analyzed. The percentage of individual destinations in the number of overnight stays, accommodation capacity, and the number of employees of broader territorial units were also determined to demonstrate their leading status. Based on the available data, we applied correlation analysis to determine the degree of reciprocity in the number of employees and the number of overnight stays. We used a linear regression model, which quantified the effect of the number of overnight stays on the number of employees. The regression analysis enabled the design of the fluctuation in the number of employees based on the fluctuation in the number of overnight stays. By looking at the data on number of employees, we can observe that a major change happened in the year 2015, which is a result of change in the way the workers are registered. In order to split the periods of different workers' registration methodology, we included a dummy variables into the regression model. With the aim of avoiding the illogicality in the number of employees assuming the inactivity of the hotel industry, the regression intercept is set to zero.

We should point out certain limitations in the methodology application. The number of employees in the hotel industry of Serbia was analyzed on the basis of available data, which were disclosed in national publications in the economy sector under the name "Accommodation and Food Services." Employees in the tourist sector of Serbia, primarily in travel agencies, are not registered separately, so their number cannot be determined using official statistical sources. The lowest territorial level for statistical monitoring of the number of employees is a municipality. However, the tourist destinations Zlatibor and Kopaonik are not separate municipalities, so we used the number of employees in the municipality of Čajetina, to which Zlatibor belongs, and the number of employees in the municipality of Raška, to which Kopaonik belongs. The abovementioned destinations are dominant in the municipalities to which they belong, the number of employees in the hotel industry of Čajetina and Raška municipalities can essentially be treated as the number of employees on Zlatibor and Kopaonik. Based on the available data and the results of correlation and regression analysis, by applying the analyticsynthetic and comparative methods, we have drawn corresponding conclusions, which can serve as the starting point for taking certain steps in the field of human resources, in the context of increasing the competitiveness of the leading tourist destinations in Serbia. 


\section{THE EFFECT OF HUMAN RESOURCES ON THE DEVELOPMENT OF LEADING CITY TOURISM DESTINATIONS IN SERBIA}

Belgrade and Novi Sad are the main carriers of city tourism development in Serbia. Their position is reflected in the biggest share of the number of overnight stays and accommodation capacity in relation to the country level, as can be seen in Table 2 .

The fluctuation in the number of tourism overnight stays was turbulent in all three destinations during the observed period, where stable growth characteristics were expressed by the number of foreign overnight stays, which increased faster in Belgrade and Novi Sad in relation to the country level, while this was not the case with accommodation capacity. A decrease in the number of overnight stays can be explained by the restructuring of the existing offer in accordance with modern European standards. However, the last two years showed an increase in accommodation capacity in Belgrade. The share of Belgrade in the total number of tourism overnight stays was $24.2 \%$ in the last year of observation. The role of Belgrade in the foreign tourism of Serbia was shown by the share in the total foreign traffic of the country, which was $63.5 \%$ in 2017 . However, the share of Belgrade in the total accommodation capacity in Serbia was only $15 \%$. This discrepancy showed that the occupancy of accommodation capacity was significantly higher in Belgrade than in Serbia.

Although much lower, the share of Novi Sad in the total (4.1\%), and in the number of foreign $(7.2 \%)$ overnight stays, as well as the total number of beds (8\%), according to 2017 data, was not negligible.

Table 2 - The number of tourism overnight stays (in 000) and accommodation capacity of leading city tourism destinations in Serbia

\begin{tabular}{cccccccccc}
\hline Year & \multicolumn{3}{c}{ Serbia } & \multicolumn{3}{c}{ Belgrade } & \multicolumn{3}{c}{ Novi Sad } \\
\hline $\begin{array}{c}\text { Total } \\
\text { overnight } \\
\text { stays }\end{array}$ & $\begin{array}{c}\text { Foreign } \\
\text { overnight } \\
\text { stays }\end{array}$ & $\begin{array}{c}\text { Number } \\
\text { of beds }\end{array}$ & $\begin{array}{c}\text { Total } \\
\text { overnight } \\
\text { stays }\end{array}$ & $\begin{array}{c}\text { Foreign } \\
\text { overnight } \\
\text { stays }\end{array}$ & $\begin{array}{c}\text { Number } \\
\text { of beds }\end{array}$ & $\begin{array}{c}\text { Total } \\
\text { overnight } \\
\text { stays }\end{array}$ & $\begin{array}{c}\text { Foreign } \\
\text { overnight } \\
\text { stays }\end{array}$ & $\begin{array}{c}\text { Number } \\
\text { of beds }\end{array}$ \\
\hline 2008 & 7334 & 1399 & 116182 & 1233 & 739 & 15892 & 185 & 95 & 2638 \\
\hline 2009 & 6762 & 1469 & 112815 & 1187 & 813 & 15585 & 162 & 97 & 2919 \\
\hline 2010 & 6414 & 1452 & 119427 & 1130 & 791 & 15688 & 168 & 100 & 4209 \\
\hline 2011 & 6645 & 1643 & 127664 & 1149 & 848 & 17014 & 214 & 143 & 10312 \\
\hline 2012 & 6485 & 1797 & 113385 & 1431 & 939 & 15874 & 231 & 151 & 3938 \\
\hline 2013 & 6567 & 1988 & 107256 & 1490 & 1036 & 15390 & 253 & 170 & 7976 \\
\hline 2014 & 6086 & 2161 & 102940 & 1535 & 1142 & 14149 & 287 & 183 & 9674 \\
\hline 2015 & 6652 & 2410 & 106102 & 1686 & 1286 & 13936 & 297 & 184 & 8278 \\
\hline 2016 & 7534 & 2739 & 109469 & 1867 & 1460 & 15389 & 361 & 242 & 9534 \\
\hline 2017 & 8325 & 3175 & 106029 & 2016 & 1620 & 15925 & 343 & 229 & 8463 \\
\hline
\end{tabular}

Source: Republic Statistical Office of Serbia: Statistical Yearbooks of the Republic of Serbia: 2009 (339,341), 2010 (339,341), 2011 (326, 328), 2012 (328, 330), 2013 (336, 338), 2014 (352, 354), 2015 (352, 354), 2016 (354, 356), $2017(384,386), 2018(350,352)$

These relations confirmed that, along with Belgrade, Novi Sad was a leading destination of city tourism in Serbia.

The following table shows the extent to which the scope of employment in the hotel industry followed the dynamics of the indicators presented in Table 3. 
Table 3 - The scope of employment in the leading city tourism destinations in Serbia (in 000)

\begin{tabular}{ccccccc}
\hline \multirow{2}{*}{ Year } & \multicolumn{2}{c}{ Serbia } & \multicolumn{2}{c}{ Belgrade } & \multicolumn{2}{c}{ Novi Sad } \\
\cline { 2 - 7 } & Total & $\begin{array}{c}\text { Accom. and } \\
\text { food services }\end{array}$ & Total & $\begin{array}{c}\text { Accom. and } \\
\text { food services }\end{array}$ & Total & $\begin{array}{c}\text { Accom. and } \\
\text { food services }\end{array}$ \\
\hline 2008 & 1428.5 & 23.6 & 465.7 & 10.3 & 102.1 & 1.1 \\
\hline 2009 & 1396.8 & 22.5 & 473.5 & 10.3 & 100.1 & 1.2 \\
\hline 2010 & 1355 & 21 & 469 & 10 & 99 & 102.2 \\
\hline 2011 & 1342.8 & 20.4 & 461.2 & 9.6 & 101.8 & 1.3 \\
\hline 2012 & 1341.1 & 20.3 & 468.7 & 10.3 & 100.5 & 1.2 \\
\hline 2013 & 1338.1 & 19.9 & 472.2 & 10.4 & 99.8 & 1.1 \\
\hline 2014 & 1323.8 & 19.8 & 470.0 & 10.7 & 136.8 & 4.8 \\
\hline 2015 & 1896.3 & 65.4 & 667.2 & 23.0 & 136.7 & 4.7 \\
\hline 2016 & 1920.7 & 67.9 & 666.7 & 23.7 & 141.6 & 5.0 \\
\hline 2017 & 1977.4 & 71.7 & 688.5 & 25.3 & & 1.3 \\
\hline
\end{tabular}

Source: Republic Statistical Office of Serbia: Municipalities in Serbia: 2009 (120-123); 2010 (120-123); Municipalities and regions in the Republic of Serbia: 2011 (128, 129); 2012 (88); 2013 (134); 2014 (152); 2015(152); 2016 (152); 2017 (152); 2018 (160).

The total scope of employment in Serbia had a negative trend until 2015. The same was the case with fluctuations in the number of employees in the sectors of accommodation and food. In Belgrade, there was an apparent increase in the sector of accommodation and food during the last three years of observation. In Novi Sad, in the sector of accommodation and food, after an increase in 2015, there was a slight decrease in 2016, and then an increase again in 2017.

In the total scope of employment, Belgrade represented Serbia with $35.5 \%$, and with almost the same share in the sector of accommodation and food (35.3\%). The share of Novi Sad was significantly lower - $7.5 \%$ in the total number of employees, and $7.0 \%$ in the number of employees in the accommodation and food sector. Belgrade is the main carrier of city tourism development, and particularly for foreign tourism development in Serbia, therefore, it is expected that a substantial scope of employment is engaged in it. Belgrade's strikingly higher share in the number of employees in the hotel industry of Serbia (35\%), compared to the number of beds (15\%), indicates the complexity and quality of the capital's hotel product, i.e., a higher share in high-class facilities characterized by the appropriate personnel.

Table 4 shows the regression analysis results for Serbia, and for leading city tourism destinations, such as Belgrade and Novi Sad. 
Table 4 - Regression analysis results for Serbia, Belgrade and Novi Sad

\begin{tabular}{|c|c|c|c|c|c|c|c|c|}
\hline \multicolumn{9}{|c|}{ Serbia (regress no. of employees d1 no. of total overnight stays, noconstant) } \\
\hline \multirow{2}{*}{$\begin{array}{l}\text { Source } \\
\text { Model }\end{array}$} & \multirow{2}{*}{$\begin{array}{l}\text { SS } \\
17144.8543\end{array}$} & \multirow{2}{*}{$\begin{array}{l}\mathrm{df} \\
2\end{array}$} & \multicolumn{2}{|c|}{ MS } & \multicolumn{2}{|c|}{ Number of obs. } & \multirow{2}{*}{$\begin{array}{l}= \\
=\end{array}$} & \multirow{2}{*}{$\begin{array}{l}10 \\
16662.95\end{array}$} \\
\hline & & & 857 & 42716 & $\mathrm{~F}(2$, & 8) & & \\
\hline Residual & 4.11568243 & 8 & .514 & 60304 & Prob & $>\mathrm{F}$ & $=$ & 0.0000 \\
\hline \multirow[t]{3}{*}{ Total } & 17148.97 & 10 & 171 & 897 & $\mathrm{R}-\mathrm{sq}$ & uared & $=$ & 0.9998 \\
\hline & & & & & Adj R & - squared & $=$ & 0.9997 \\
\hline & & & & & Root 1 & MSE & $=$ & .71726 \\
\hline \multicolumn{2}{|c|}{ No. of employees } & Coef. & Std. Err. & $\mathrm{t}$ & & $>|\mathrm{t}|$ & [95\% Conf. & Interval] \\
\hline \multicolumn{2}{|l|}{$\mathrm{d} 1$} & 44.40457 & .5151736 & 86.19 & & 000 & 43.21657 & 45.59256 \\
\hline \multicolumn{2}{|c|}{ No. of. total overnight stays } & .0031889 & .0000408 & 78.08 & 0. & 00 & .0030948 & .0032831 \\
\hline
\end{tabular}

Belgrade (regress no. of employees d1 no. of total overnight stays, noconstant)

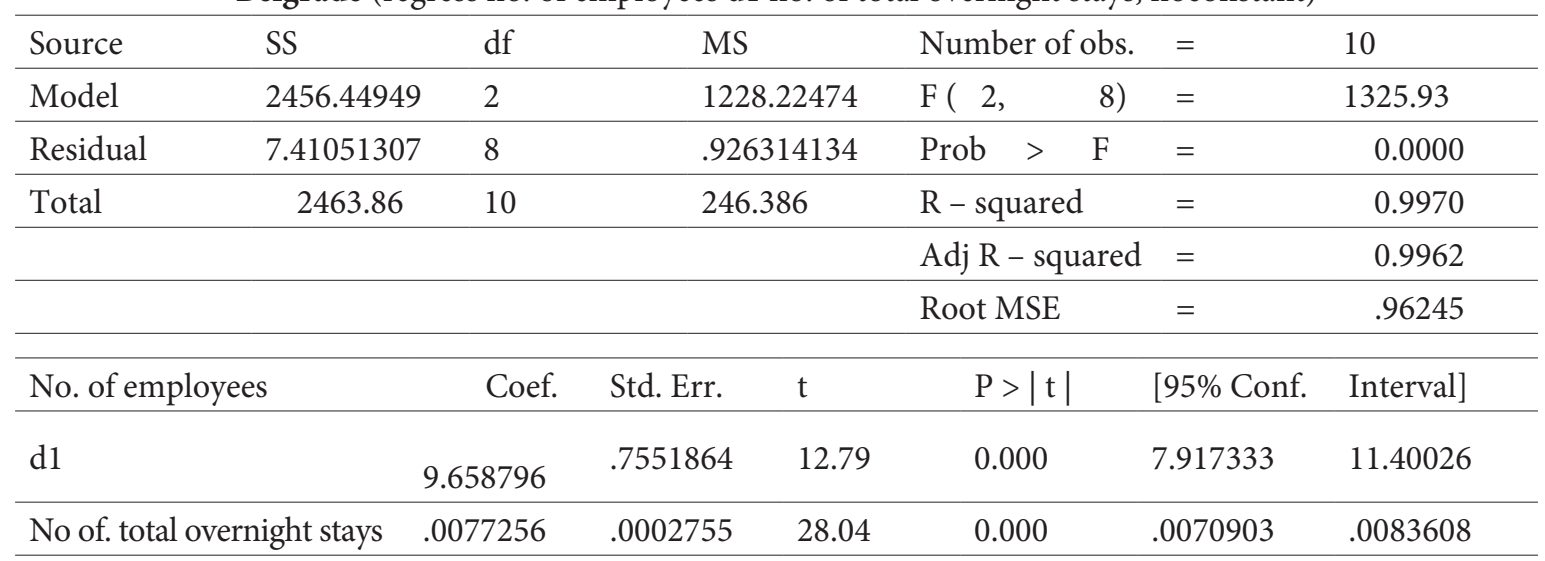

Novi Sad (regress no. of employees d1 no. of total overnight stays, noconstant)

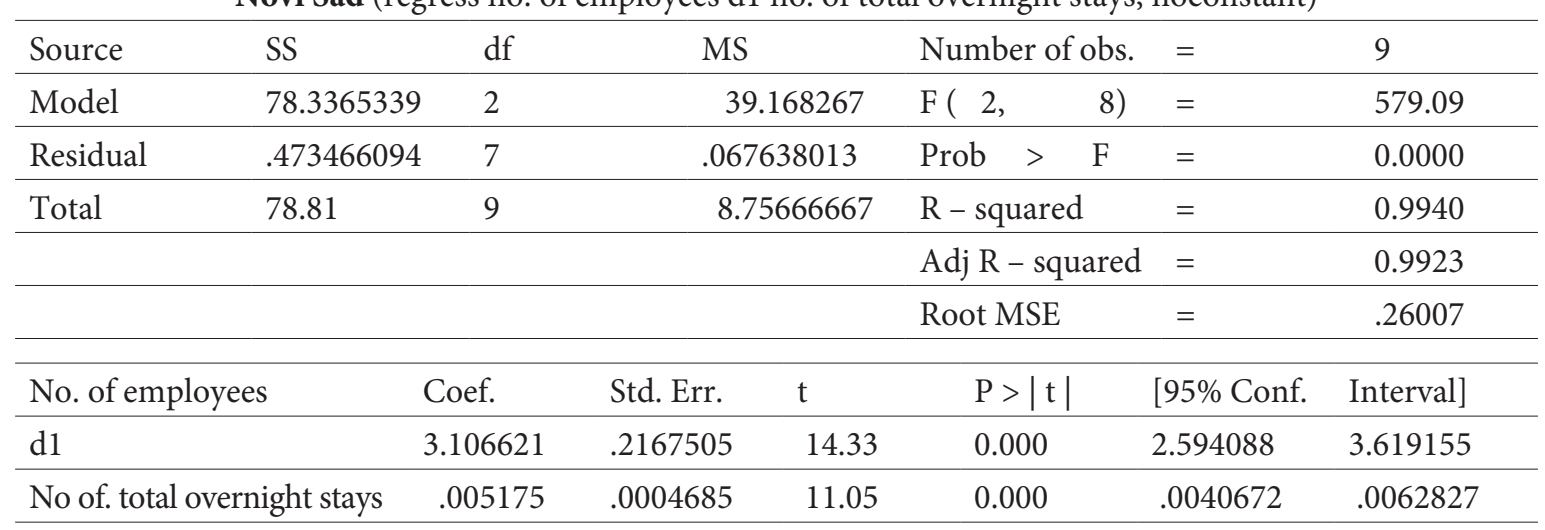

Predictors: (Constant): Overnight stays; Dependent Variable: Employees Source: Derived on the basis of the data contained in Tables 2 and 3; STATA Statistics

The results show that the regression model is statistically significant. The coefficient of determination value ( $\mathrm{R}$ - squared) indicates that more than $99 \%$ variations of the dependent variable (the number of employees) can be explained by changes in the number of overnight stays. The regression equation for Serbia is: $y=0.0031889 x$. According to this result, one person should be employed in the hotel industry for every 314 nights per year.

The regression equation for Belgrade is: $y=0.0077256 x$. According to this result, one person should be employed in the hotel industry for every 129 nights per year. 
The regression equation for Novi Sad is: $y=0.005175 x$. According to this result, one person should be employed in the hotel industry for every 193 nights per year.

Differences in employment needs depending on the number of nights can be explained by the type of accommodation facilities and by the assortment of offered services.

\section{THE EFFECT OF HUMAN RESOURCES ON THE DEVELOPMENT OF LEADING SPA TOURISM DESTINATIONS IN SERBIA}

Vrnjačka Banja and Sokobanja are the leading spa tourism destinations in Serbia. This has been confirmed by their share in the total number of overnight stays and the accommodation capacity of spa resorts. The dominant position of Vrnjacka Banja in the spa tourism in Serbia has been shown by its share in the total number of tourism overnightstays of spa resorts, which amounted to 31.5\% in 2017. The share in the total number of beds was at $17.4 \%$, so it can be concluded that the accommodation capacity of Vrnjacka Banja was much better occupied compared to the average in Serbian spa resorts. Although much lower, the share of Sokobanja in the total number of overnight stays of spa resorts, which amounted to $11.8 \%$ in 2017 , was also remarkable. The number of tourism overnight stays in Sokobanja had a less favorable trend compared to the average in Serbian spa resorts. The share of Sokobanja in the accommodation capacity of spa resorts in Serbia amounted to $23.6 \%$ in 2017. Compared to Vrnjačka Banja, Sokobanja had a lower share in the number of tourism overnight stays, and a higher share in the accommodation capacity of spa resorts in Serbia. This implies insufficient occupancy of accommodation capacity in Sokobanja.

Table 5 - The number of tourism overnight stays (in 000) and accommodation capacity in spa tourism resorts in Serbia, in Vrnjačka Banja and Sokobanja

\begin{tabular}{cccccccccc}
\hline Year & \multicolumn{2}{c}{ Spa tourism resorts } & \multicolumn{3}{c}{ Vrnjačka Banja } & \multicolumn{3}{c}{ Sokobanja } \\
\hline $\begin{array}{c}\text { Total } \\
\text { overnight } \\
\text { stays }\end{array}$ & $\begin{array}{c}\text { Foreign } \\
\text { overnight } \\
\text { stays }\end{array}$ & $\begin{array}{c}\text { Number } \\
\text { of beds }\end{array}$ & $\begin{array}{c}\text { Total } \\
\text { overnight } \\
\text { stays }\end{array}$ & $\begin{array}{c}\text { Foreign } \\
\text { overnight } \\
\text { stays }\end{array}$ & $\begin{array}{c}\text { Number } \\
\text { of beds }\end{array}$ & $\begin{array}{c}\text { Total } \\
\text { overnight } \\
\text { stays }\end{array}$ & $\begin{array}{c}\text { Foreign } \\
\text { overnight } \\
\text { stays }\end{array}$ & $\begin{array}{c}\text { Number } \\
\text { of beds }\end{array}$ \\
\hline 2008 & 2368 & 101 & 42243 & 539 & 39 & 7169 & 393 & 4 & 14165 \\
\hline 2009 & 2287 & 97 & 36919 & 609 & 41 & 6011 & 321 & 5 & 14097 \\
\hline 2010 & 2211 & 104 & 37306 & 560 & 45 & 6138 & 295 & 5 & 14067 \\
\hline 2011 & 2308 & 132 & 37445 & 579 & 50 & 6144 & 325 & 4 & 14137 \\
\hline 2012 & 2035 & 134 & 35543 & 506 & 51 & 5620 & 307 & 3 & 13933 \\
\hline 2013 & 2134 & 181 & 26536 & 595 & 63 & 13110 & 307 & 5 & 6786 \\
\hline 2014 & 1852 & 201 & 24399 & 498 & 66 & 4144 & 220 & 11 & 6194 \\
\hline 2015 & 1855 & 231 & 25459 & 563 & 82 & 4232 & 195 & 11 & 5972 \\
\hline 2016 & 2085 & 254 & 26343 & 678 & 104 & 4342 & 219 & 7 & 6238 \\
\hline 2017 & 2228 & 271 & 25207 & 702 & 98 & 4396 & 262 & 7 & 5958 \\
\hline
\end{tabular}

Source: Republic Statistical Office of Serbia: Statistical Yearbooks of the Republic of Serbia: 2009 (341), 2010 (341), 2011 (328), 2012 (330), 2013 (336-338), 2014 (352-354), 2015 (352-354), 2016 (354-356), 2017 (384-386), 2018 (350-352) 
A decrease in the number of beds in the observed period was a result of insufficient adaptation to modern market requirements and, accordingly, the restructuring of the existing capacity.

Vrnjačka Banja is the leading tourist destination in the Raška District. This was indicated by the share of the total scope of employment in the accommodation and food sector, which amounted to as much as $42.9 \%$ in 2008. At the end of the observed period, there was a decrease in the share of Vrnjacka Banja in the total number of employees in the hotel industry, which was $24.3 \%$.

However, the already high share of Vrnjačka Banja in the number of tourism overnight stays of Raška District of $44.0 \%$ in 2008, increased further to $56.7 \%$ in 2017. Thus, it can be concluded that the number of overnight stays in Vrnjačka Banja was not accompanied by appropriate dynamics of the number of employees in the hotel industry.

Table 6 shows how the scope of employment fits into the established relations.

Table 6 - Scope of employment in the leading spa tourism destinations in Serbia (in 000)

\begin{tabular}{|c|c|c|c|c|c|c|c|c|}
\hline \multirow[t]{2}{*}{ Year } & \multicolumn{2}{|c|}{ Raška District } & \multicolumn{2}{|c|}{ Vrnjačka Banja } & \multicolumn{2}{|c|}{ Zaječar District } & \multicolumn{2}{|c|}{ Sokobanja } \\
\hline & Total & $\begin{array}{c}\text { Accomm. } \\
\text { and food } \\
\text { services }\end{array}$ & Total & $\begin{array}{l}\text { Accomm. } \\
\text { and food } \\
\text { services }\end{array}$ & Total & $\begin{array}{c}\text { Accomm. } \\
\text { and food } \\
\text { services }\end{array}$ & Total & $\begin{array}{c}\text { Accomm. } \\
\text { and food } \\
\text { services }\end{array}$ \\
\hline 2008 & 41.8 & 1.4 & 5.1 & 0.6 & 20.7 & 0.3 & 2.5 & 0.2 \\
\hline 2009 & 40.6 & 1.1 & 5.1 & 0.5 & 18.9 & 0.3 & 2.4 & 0.2 \\
\hline 2010 & 39.0 & 1.0 & 5.0 & 0 & 17.0 & 0 & 2.0 & 0 \\
\hline 2011 & 38.1 & 1.0 & 4.5 & 0.4 & 17.0 & 0.3 & 2.3 & 0.2 \\
\hline 2012 & 37.5 & 1.0 & 4.0 & 0.4 & 16.3 & 0.3 & 2.2 & 0.2 \\
\hline 2013 & 37.3 & 1.0 & 4.0 & 0.3 & 16.3 & 0.3 & 2.2 & 0.2 \\
\hline 2014 & 36.6 & 0.8 & 3.7 & 0.2 & 15.5 & 0.2 & 2.0 & 0.2 \\
\hline 2015 & 61.0 & 3.2 & 6.1 & 0.7 & 22.5 & 0.9 & 2.9 & 0.2 \\
\hline 2016 & 61.7 & 3.6 & 6.6 & 0.9 & 22.1 & 0.9 & 3.0 & 0.2 \\
\hline 2017 & 64.2 & 3.7 & 6.9 & 0.9 & 22.2 & 1.0 & 3.0 & 0.3 \\
\hline
\end{tabular}

Source: Republic Statistical Office of Serbia: Municipalities in Serbia: 2009 (125,127); 2010 (125, 127); Municipalities and regions in the Republic of Serbia: 2011(133, 135); 2012 (92, 94); 2013 (138, 140); 2014 (156, 158); 2015 (156, 158); 2016 (156, 158); 2017 (156, 158); 2018 (164, 166).

In the Zaječar District, the dominance of Sokobanja was even more prominent, judging by the share in the total number of overnight stays at the beginning (75.8\%) and end (69.2\%) of the observed period. The share of Sokobanja in the total number of employees in the hotel industry of the Zaječar District ranged from $66.7 \%$ in 2008 to $30 \%$ in 2017. A decline of the Sokobanja share in the total number of overnight stays was followed by a more rapid decline in the share in the number of employees in the Zaječar District hotel industry.

The results of regression analysis for the leading Serbian spa tourist destinations, such as Vrnjačka Banja and Sokobanja, are shown in Table 7.

Statistical significance can be noticed. The value of the coefficient of determination ( $\mathrm{R}$ - squared) indicates that more than $90 \%$ variations of the dependent variable (the number of employees) can be explained by changes in the number of overnight stays. The regression equation for Vrnjačka Banja is: $y=0.0006226 x$. According to this result, one person should be employed in the hotel industry for every 1,608 nights per year. The regression equation for Sokobanja is: $y=0.0005487 x$. According to this result, one person should be employed in the hotel industry for every 1,822 nights per year. 
The regression model shows much slower employment dynamics in the hotel industry in spa resorts than in city resorts. This is due to the structure of the type of accommodation in spa resorts, mostly oriented towards private houses and apartments, where a large number of employees is not required.

Table 7 - Regression analysis results for Vrnjačka Banja and Sokobanja

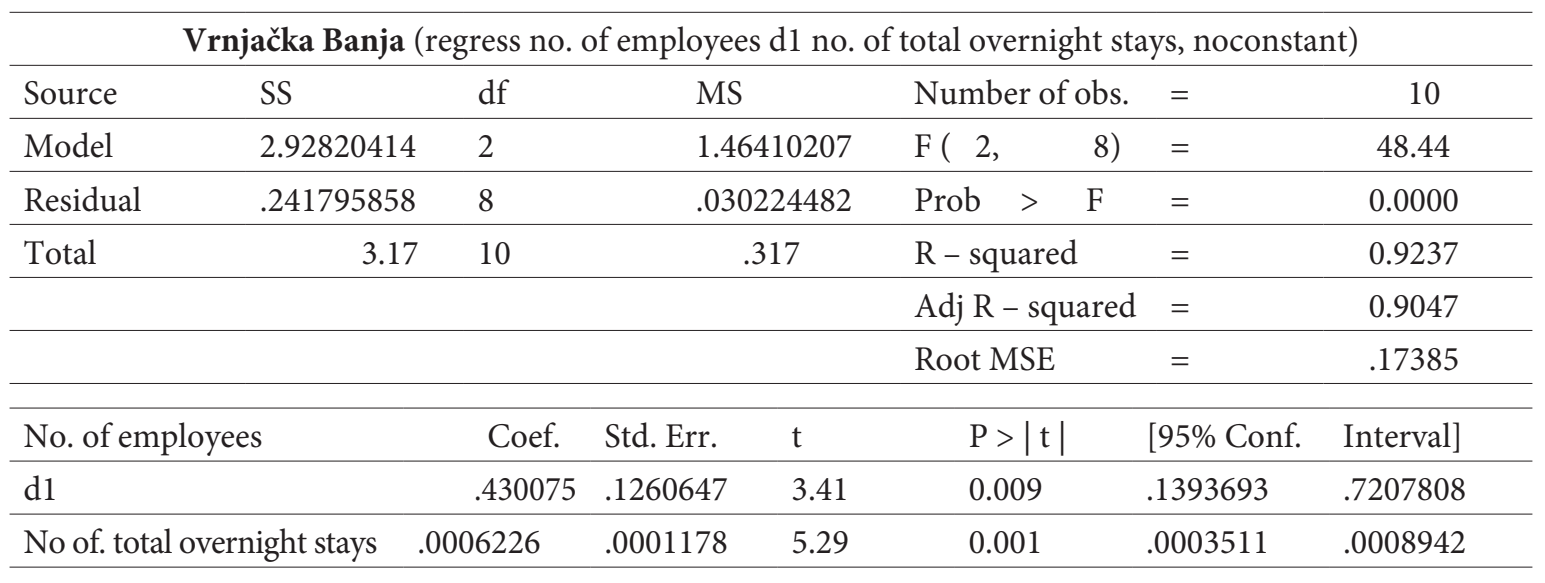

Sokobanja (regress no. of employees d1 no. of total overnight stays, noconstant)

\begin{tabular}{lllrlrc}
\hline Source & SS & df & MS & Number of obs. & & 10 \\
Model & .370901613 & 2 & .185450806 & F $(2, \quad 8)$ & $=$ & 37.95 \\
\hline Residual & .039098387 & 8 & .004887298 & Prob $>$ F & $=$ & 0.0001 \\
\hline Total & .41 & 10 & .041 & R - squared & $=$ & 0.9046 \\
\hline & & Adj R - squared & $=$ & 0.8808 \\
\hline & & Root MSE & $=$ & .06991 \\
\hline
\end{tabular}

\begin{tabular}{lcccccc}
\hline No. of employees & Coef. & Std. Err. & $\mathrm{t}$ & $\mathrm{P}>|\mathrm{t}|$ & [95\% Conf. & Interval] \\
\hline $\mathrm{d} 1$ & .109685 & .0445992 & 2.46 & 0.039 & .0068391 & .2125308 \\
\hline No of. total overnight stays & .0005487 & .0000842 & 6.52 & 0.000 & .0003546 & .0007429 \\
\hline
\end{tabular}

Predictors: (Constant): Overnight stays; Dependent Variable: Employees

Source: Derived on the basis of the data contained in Tables 5 and 6; STATA Statistics

\section{THE EFFECT OF HUMAN RESOURCES ON THE DEVELOPMENT OF LEADING MOUNTAIN TOURISM DESTINATIONS IN SERBIA}

Mountain tourism, along with spa tourism, is the main form of stationary tourism in Serbia. Zlatibor and Kopaonik are the leading destinations of mountain tourism in this country, as evidenced by the data presented in Table 8.

Table 9 shows the scope of employment in Zlatibor and Kopaonik.

In the total number of overnight tourism stays at Serbian mountain resorts, Zlatibor, according to the 2017 data, had a share of $34.4 \%$. When it comes to Kopaonik, its share in the same year amounted to $26.5 \%$. In 2017, there were $26.7 \%$ of beds on Zlatibor and $29.6 \%$ on Kopaonik, of the total number of beds in the mountain tourism resorts of Serbia. These figures indicate a high degree of concentration of mountain tourism in Serbia, given the distinct dominance of the two mountain tourism destinations.

The municipality of Čajetina had a share of $32.4 \%$ in the total number of employees in the hotel industry of the Zlatibor District in 2017. That same year, the municipality of Čajetina achieved as much as $74.9 \%$ of 
the total number of overnight stays in the Zlatibor District. Observed dynamically, based on the presented data, it can be concluded that an increase in the number of tourism overnight stays on Zlatibor, as well as in the municipality of Čajetina, was not accompanied by an adequate increase in the number of employees.

Table 8 - The number of overnight tourism stays and accommodation capacity in the leading mountain tourism destinations of Serbia (in 000)

\begin{tabular}{cccccccccc}
\hline Year & \multicolumn{2}{c}{ Spa tourism resorts } & \multicolumn{3}{c}{ Vrnjačka Banja } & \multicolumn{3}{c}{ Sokobanja } \\
\hline $\begin{array}{c}\text { Total } \\
\text { overnight } \\
\text { stays }\end{array}$ & $\begin{array}{c}\text { Foreign } \\
\text { overnight } \\
\text { stays }\end{array}$ & $\begin{array}{c}\text { Number } \\
\text { of beds }\end{array}$ & $\begin{array}{c}\text { Total } \\
\text { overnight } \\
\text { stays }\end{array}$ & $\begin{array}{c}\text { Foreign } \\
\text { overnight } \\
\text { stays }\end{array}$ & $\begin{array}{c}\text { Number } \\
\text { of beds }\end{array}$ & $\begin{array}{c}\text { Total } \\
\text { overnight } \\
\text { stays }\end{array}$ & $\begin{array}{c}\text { Foreign } \\
\text { overnight } \\
\text { stays }\end{array}$ & $\begin{array}{c}\text { Number } \\
\text { of beds }\end{array}$ \\
\hline 2008 & 1912 & 136 & 21782 & 436 & 46 & 3917 & 423 & 41 & 4741 \\
\hline 2009 & 1673 & 125 & 21817 & 389 & 44 & 3771 & 324 & 30 & 4742 \\
\hline 2010 & 1467 & 129 & 22808 & 404 & 52 & 4890 & 234 & 24 & 4325 \\
\hline 2011 & 1590 & 148 & 22379 & 483 & 65 & 4629 & 271 & 29 & 4018 \\
\hline 2012 & 1601 & 155 & 24209 & 463 & 62 & 5404 & 298 & 37 & 4480 \\
\hline 2013 & 1558 & 194 & 20551 & 456 & 67 & 4814 & 341 & 48 & 4221 \\
\hline 2014 & 1412 & 215 & 20646 & 427 & 79 & 5110 & 323 & 51 & 4437 \\
\hline 2015 & 1661 & 242 & 21222 & 557 & 101 & 5936 & 427 & 64 & 5404 \\
\hline 2016 & 1929 & 287 & 22709 & 652 & 120 & 6306 & 496 & 89 & 4563 \\
\hline 2017 & 2079 & 321 & 22604 & 714 & 132 & 6030 & 551 & 105 & 6686 \\
\hline
\end{tabular}

Source: Republic Statistical Office of Serbia: Statistical Yearbooks of the Republic of Serbia: 2009 (341), 2010 (341), 2011 (328), 2012 (330), 2013 (336-338), 2014 (352-354), 2015 (352-354), 2016 (354-356), 2017 (384-386), 2018 (350-352)

The share of the Raška Municipality in the total number of employees in the hotel industry of the Raška District amounted to $18.9 \%$ in 2017. That same year, the share of Raška in the total number of overnight stays in the Raška District was 35.3\%. The number of employees in the municipality of Raška and, therefore, on Kopaonik, showed an unfavorable fluctuation dynamic compared to the number of overnight tourism stays.

Table 9 - Scope of employment in the leading mountain tourism destinations in Serbia (in 000)

\begin{tabular}{|c|c|c|c|c|c|c|c|c|}
\hline \multirow[t]{2}{*}{ Year } & \multicolumn{2}{|c|}{ Zlatibor District } & \multicolumn{2}{|c|}{ Čajetina } & \multicolumn{2}{|c|}{ Raška District } & \multicolumn{2}{|c|}{ Raška } \\
\hline & Total & $\begin{array}{l}\text { Accomm. } \\
\text { and food } \\
\text { services }\end{array}$ & Total & $\begin{array}{l}\text { Accomm. } \\
\text { and food } \\
\text { services }\end{array}$ & Total & $\begin{array}{c}\text { Accomm. } \\
\text { and food } \\
\text { services }\end{array}$ & Total & $\begin{array}{c}\text { Accomm. } \\
\text { and food } \\
\text { services }\end{array}$ \\
\hline 2008 & 47.8 & 1.4 & 2.8 & 0.7 & 41.8 & 1.4 & 4.0 & 0.5 \\
\hline 2009 & 46.0 & 1.3 & 2.6 & 0.6 & 40.6 & 1.1 & 3.4 & 0.3 \\
\hline 2010 & 45.0 & 1.0 & 3.0 & 1.0 & 39.0 & 1.0 & 3.0 & 0 \\
\hline 2011 & 44.3 & 1.2 & 2.8 & 0.7 & 38.1 & 1.0 & 3.6 & 0.2 \\
\hline 2012 & 44.2 & 1.1 & 2.8 & 0.6 & 37.5 & 1.0 & 3.2 & 0.3 \\
\hline 2013 & 43.5 & 1.1 & 2.9 & 0.7 & 37.3 & 1.0 & 3.2 & 0.3 \\
\hline 2014 & 42.7 & 1.0 & 2.8 & 0.6 & 36.6 & 0.8 & 3.2 & 0.3 \\
\hline 2015 & 65.8 & 3.3 & 4.4 & 1.1 & 61.0 & 3.2 & 5.0 & 0.6 \\
\hline 2016 & 65.3 & 3.3 & 4.5 & 1.1 & 61.7 & 3.6 & 5.5 & 0.7 \\
\hline 2017 & 66.4 & 3.4 & 4.8 & 1.1 & 64.2 & 3.7 & 5.5 & 0.7 \\
\hline
\end{tabular}

Source: Republic Statistical Office of Serbia: Municipalities in Serbia: 2009 (124.126); 2010 (133, 135); Municipalities and regions in the Republic of Serbia: 2011 (131, 133); 2012 (90, 92); 2013 (136, 148); 2014 (154, 156); 2015 (154, 156); 2016 (154, 156); 2017 (154, 156); 2018 (162, 164). 
Table 10 shows the results of regression analysis for Zlatibor and Kopaonik.

Results are statistically significant, and they indicate that more than $95 \%$ variations of the dependent variable (the number of employees) can be explained by changes in the number of overnight stays. The regression equation for Zlatibor is: $y=0.0015748 x$. According to this result, one person should be employed in the hotel industry for every 635 nights per year.

The regression equation for Kopaonik is: $y=0.0009022 x$. According to this result, one person should be employed in the hotel industry for every 1,108 nights per year.

The slower employment dynamics in the hotel industry of Kopaonik compared to Zlatibor should be connected to the differences in the structure of the accommodation offer. Recently in Zlatibor, first-class and luxury hotels that employ a large number of employees have been built. Furthermore, seasonality is less pronounced on Zlatibor than on Kopaonik.. This also affects the faster growth of employees in connection with the movement of the number of overnight tourism stays. Similar to the observed leading spa resorts, there is a strong orientation towards private apartment accommodation, which does not require a large number of employees on Kopaonik.

Table 10 - Results of regression analysis for Zlatibor (Čajetina) and Kopaonik (Raška)

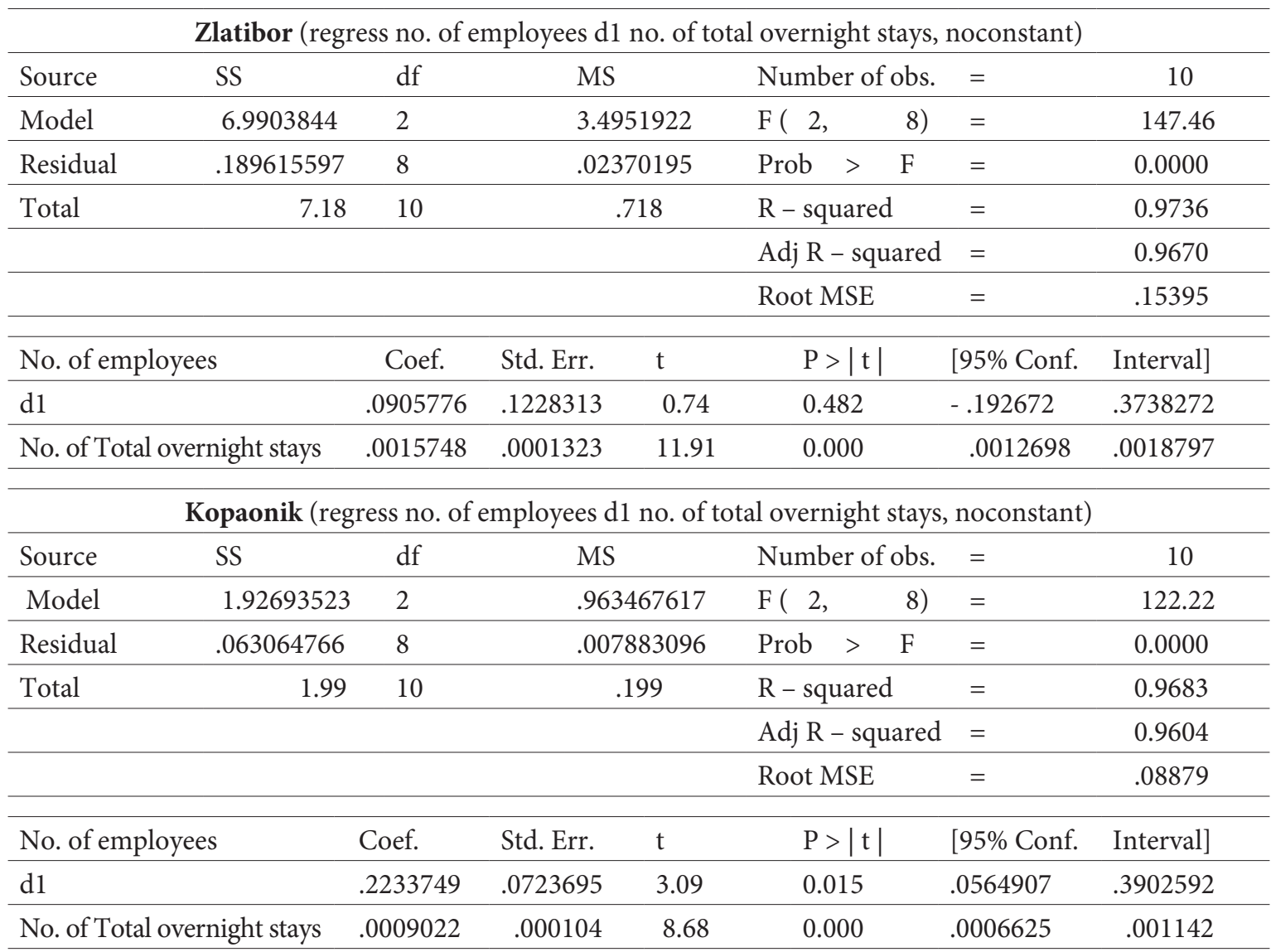

Predictors: (Constant): Overnight stays; Dependent Variable: Employees

Source: Derived on the basis of the data contained in Tables 8 and 9; STATA Statistics 


\section{CONCLUSION}

The destination approach amounted to the study of tourism insists on the quality of hotel and tourism products. The substitution process is present in tourism. Due to the existence of destinations with the same type of tourist attractions, the quality of the hotels' offer should be expressed as a comparative advantage. It doesn't refer solely to the technical aspect of quality, but to the human dimension of a hotel service as well. So, we can conclude that human resources in the hotel industry should be an important factor of tourism destination comparative advantage. Given that human resources are a key component of hotel and tourism product quality, an assessment of their effect on the future development of tourism is inevitable.

The basic contribution of this paper is reflected in the statistically proven correlation between the number of employees and the number of overnight stays. The application of the regression model showed that the required number of employees can be predicted depending on the number of overnight stays. The scope of employment is a quantitative framework for undertaking further qualitative research of human resources at the level of a tourist destination. It is about research where the focus should be on the qualifications, knowledge and skills of employees, according to the needs of consumers.

The research results obtained from this paper indicate problems related to employment in the tourism and hotel industry of Serbia, and that it is lagging behind the world and region, something which must be considered as one of the major limiting factors for future development. The competitiveness of tourist destinations and the effect of human resources on the development of tourist destinations have been approached in terms of an analysis of the relationship between the number of employees in the hotel industry, the number of overnight stays, and the volume of accommodation capacity in the leading destinations of the city, mountain and spa tourism in Serbia. We have found a turbulent, mainly unfavorable fluctuation in all the indicators as a result of the insufficient commitment to the strategic market positioning of Serbia as a tourist destination.

The stabilization and the signs of positive development have become evident in recent years. However, it seems that the growth dynamic of accommodation capacity is not a result of planned activities since it is not accompanied by an adequate increase in employment. The primary orientation towards accommodation in private houses results in an increase in the number of overnight stays, but not in an increase in employment. Service providers in private houses remain largely outside the registration of the number of employees in the accommodation and F\&B sector.

On the other hand, given the established regression, an increase in the number of overnight tourism stays should lead to an increase in the number of employees in the hotel industry. New personnel should contribute to increasing the quality of hotel and tourism products. They should be the initiators of activities regarding the hotel offer restructuring, repositioning in the market and increasing the competitiveness of Serbia and its leading tourist destinations. 


\section{REFERENCES}

Ahammad, T. (2017). Personnel Management to Human Resource Management (HRM): How HRM Functions? Journal of Modern Accounting and Auditing, 13(9), 412-420. doi: 10.17265/1548-6583/2017.09.004

Baum, T. (2007). Human resources in tourism: Still waiting for change. Tourism Management, 28 1383-1399. doi:10.1016/j.tourman.2007.04.005

Brewster, C., Sparrow, P., Vernon, G. \& Houldsworth, E. (2011). International Human Resource Management. London: Chartered Institute of Personnel and Development.

Čerović, S. (2013). Upravljanje ljudskim resursima u hotelijerstvu. Belgrade: „Singidunum“ University.

Goeldner, R.C. \& Brent Ritchie, J. R. (2009). Tourism, Principles, Practices, Philosophies. New Jersey: John Willey \& Sons.

Gruescu, R., Nanu, R. \& Tanasie, A. (2009). Human Resources Development and ICT Contribution to the Tourist Destination Competitiveness. European Research Studies, 12 (4), 87-100

Hoque, K. (2013). Human Resource Management in the Hotel Industry, Strategy, innovation and performance. London: Routledge. https://doi.org/10.4324/9780203020869

Kordić, N. \& Milićević, S. (2018). Human resources in the hotel industry of Serbia. Hotel and Tourism Management. 6(1), 93-103. DOI: 10.5937/menhottur1801093k

Kosar, Lj. \& Kordić, N. (2018). Transformation of the Hotel Product in the Digital Age. In 3nd International Scientific Conference, Thematic Proceedings I Tourism in Function of Development of the Republic of Serbia - Tourism in the Era of Digital Transformation, 31 May-2 June, 2018 (pp. 95-112). Vrnjačka Banja: University of Kragujevac - Faculty of Hotel Management and Tourism in Vrnjačka Banja.

Kosar, Lj. \& Rašeta, S. (2005). Izazovi kvaliteta - Menadžment kvaliteta u hotelijerstvu. Belgrade: The College of Hotel Management.

Mazanec, J., Wober, K. \& Zins, A. (2007). Tourism Destination Competitiveness: From Definition to Explanation? Journal of Travel research, 46(1), 86-95. https://doi.org/10.1177/0047287507302389

Milićević, S. \& Đorđević, N. (2016). Glavni gradovi kao turističke destinacije. Menadžment u hotelijerstvu i turizmu (HiT Menadžment), 4(1), 21-30. UDK:338.48-44(1-21)

Milićević, S. \& Petrović, J. (2018). Ljudski resursi u funkciji konkurentnosti Evropske Unije kao turističke destinacije. BizInfo (Blace), 9 (2), 53-63. doi: 10.5937/bizinfo1802053M.

Ministry of Trade, Tourism and Telecommunications. (2016). Strategy for tourism development of the Republic of Serbia for the period 2016-2025. Belgrade: https://www.Serbia.gov.rs/dokument/45678/strategije.php Retrieved March 3, 2019.

Pekaar, K., Linden, D., Bakker, A. \& Born, M. (2017). Emotional intelligence and job performance: The role of enactment and focus on others' emotions. Human Performance, 30(2-3), 135-153, DOI: $10.1080 / 08959285.2017 .1332630$

Petrović, J. \& Stanišić, T. (2015). Knowledge as a factor of economic growth of transition countries. FACTA UNIVERSITATIS, Series: Economics and Organisation, 12(2), 97-108.

Popesku, J. (2011). Menadžment turističke destinacije. Belgrade: „Singidunum“ University.

Republic Statistical Office of Serbia. Statistical Yearbooks of the Republic of Serbia: 2009 (339,341), 2010 (339,341), 2011 (326, 328), 2012 (328, 330), 2013 (336, 338), 2014 (352, 354), 2015 (352, 354), 2016 (354, 356), 2017 (384, 386), 2018 (350, 352). Belgrade. http://publikacije.stat.gov.rs/ Retrieved March 10, 2019.

Republic Statistical Office of Serbia. Municipalities in Serbia: 2009 (120-123); 2010 (120-123). Belgrade. http:// publikacije.stat.gov.rs/ Retrieved March 10, 2019.

Republic Statistical Office of Serbia. Municipalities and regions in the Republic of Serbia: 2011 (128, 129); 2012 (88); 2013 (134); 2014 (152); 2015 (152); 2016 (152); 2017 (152); 2018 (160). Belgrade. http://publikacije.stat. gov.rs/ Retrieved March 10, 2019.

Ritchie, B. \& Crouch, G.(2010). A model of destination competitiveness/sustainability: Brazilian perspectives. RAP - Rio de Janeiro, 44(5), 1049-66. 
Saraniemi, S. \& Kylänen, M. (2011). Problematizing the Concept of Tourism Destination: An Analysis of Different Theoretical Approaches. Journal of Travel Research, 50(2), 133-143. DOI: 10.1177/0047287510362775 http://jtr.sagepub.com.

Sharaeva, M. (2016). Human resource management in crisis: motivation of employees. Journal of Economics and Social Sciences. 8, 29-31.

Stasiak, A. (2013). Tourist Product in Experience Economy. Tourism, 23(1), 27-35, DOI 10.2478/tour-2013-0003.

Teodorović, M. \& Popesku, J. (2017). Serbia’s competitive position in the regional tourism destination market. The European Journal of Applied Economics, 14(1), 1-12.

Unković, S. (2017). Talent development and education in tourism. The European Journal of Applied Economics, 14(1), 70-75.

UNWTO. (2018). Tourism Highlights Edition, World Tourism Organisation, https://www.e-unwto.org/doi/ pdf/10.18111/9789284419876 Retrieved March 1, 2019.

Vengesayi, S., Mavondo, F. \& Reisinger, Y. (2013). Tourism Destination Competitiveness: The impact of Destination Resources, Support Services and Human Factors. Journal of Tourism, 14(1), 79-108.

Wolfe, K. \& Kim, H. (2013). Emotional Intelligence, Job Satisfaction, and Job Tenure among Hotel Managers. Journal of Human Resources in Hospitality \& Tourism, 12(2), 175-191. https://doi.org/10.1080/15332845.2013.752710

WTTC. (2018). TRAVEL \& TOURISM ECONOMIC IMPACT World. https:/www.wttc.org/-/media/files/ reports/economic-impact-research/regions-2018/world2018.pdf,

WTTC. (2018). TRAVEL \& TOURISM ECONOMIC IMPACT Country-data https://ww.wttc.org/-/media/files/ reports/economic-impact-research/countries-2018, Retrieved March 5, 2019.

WTTC. (2018). TRAVEL \& TOURISM ECONOMIC IMPACT Serbia https://www.wttc.org/-/media/.../reports/...2018/ serbia2018.pdf Retrieved March 7, 2019. 


\section{UTICAJ LJUDSKIH RESURSA NA RAZVOJ VODEĆIH TURISTIČKIH DESTINACIJA U SRBIJI}

\section{Rezime:}

Cilj rada je da pokaže povezanost između obima i dinamike turističkog prometa i smeštajnih kapaciteta i obima i dimamike zapošljavanja u hotelijerstvu Srbije. Za predmet istraživanja izabrane su najrazvijenije turističke destinacije Srbije (na polju gradskog turizma, Beograd i Novi Sad, banjskog turizma, Vrnjačka Banja i Sokobanja i planinskog turizma, Zlatibor i Kopaonik). Prvi deo rada govori o povezanosti izučavanja turističke destinacije, s jedne i ljudskih resursa, s druge strane. U drugom delu rada se prezentuje kvantifikacija uticaja zaposlenosti na broj noćenja u vodećim turističkim destinacijama Srbije, zasnovana na korelacionoj i regresionoj analizi i izvode zaključci primenom analitičko-sintetičkog i komparativnog metoda.

\section{Ključne reči:}

turistička destinacija, zaposlenost, broj noćenja, smeštajni kapacitet, Srbija. 